\title{
Nucleobase clustering contributes to the formation and hollowing of repeat-expansion RNA condensate
}

\author{
Ying-Xue Ma ${ }^{[a], \S}$, Hao-Zheng Li ${ }^{[c],}$, Zhou Gong ${ }^{[a]}$, Shuai Yang ${ }^{[a]}$, Ping Wang ${ }^{*[c]}$, Chun Tang ${ }^{*[b]}$
}

[a] Innovation Academy for Precision Measurement Science and Technology, Chinese Academy of Sciences, Wuhan, Hubei 430071, China

[b] Beijing National Laboratory for Molecular Sciences, College of Chemistry and Molecular Engineering, and Peking-Tsinghua Center for Life Sciences, Peking University, Beijing 100871, China; Email: tang_chun@pku.edu.cn (C.T.)

[c] Britton Chance Center for Biomedical Photonics, Wuhan National Laboratory for Optoelectronics-Huazhong University of Science and Technology, Wuhan Hubei 430074, China; E-mail: p_wang@hust.edu.cn (P.W.)

$\S \quad$ These authors contributed equally to this work

Supporting information for this article is given via a link at the end of the document

\begin{abstract}
RNA molecules with repeat expansion sequences can phase separate into gel-like condensate, and this process may lead to neurodegenerative diseases. Here we report that in the presence of $\mathrm{Mg}^{2+}$ ion, RNA molecules containing 20×CAG repeats coacervate into filled droplets or hollowed condensate. Using hyperspectral stimulated Raman spectroscopy, we show that RNA coacervation is accompanied by the stacking and clustering of nucleobases, while forfeiting the canonical base-paired structure. At an increasing $\mathrm{RNA} / \mathrm{Mg}^{2+}$ ratio, the RNA droplets first expand in sizes, and then shrink and adopt hollow vesicle-like structures. Significantly, for both large and vesicle-like droplets, the nucleobase-clustered structure is more prominent at the rim than at the center, accounting for the rigidification of RNA droplets. Thus, our finding has broad implications for the general aging processes of RNA-containing membrane-less organelles.
\end{abstract}

Liquid-liquid phase separation (LLPS) has been increasingly recognized for its relevance in a multitude of biological processes, ${ }^{[1]}$ which enables molecules to form membrane-less organelles. Aberrant phase separation, on the other hand, would lead to the formation of pathological amyloids, hydrogels, or amorphous aggregates, often implicated in neurodegenerative diseases. ${ }^{[2]}$ The research on LLPS has been largely focused on proteins comprising intrinsically disordered or low-complexity regions. ${ }^{[2 a, 3]}$ Yet, LLPS also occurs between proteins and RNAs. ${ }^{[1 ;, 4]}$ Moreover, repeat-expansion RNAs alone may undergo phase separation without the involvement of proteins. ${ }^{[5]}$ Significantly, RNA condensates usually age rapidly and form gel-like structures with little mobility and fluidity. Therefore, the phase separation of RNA molecules, as opposed to the RNAencoded proteins, has been proposed to be the etiology of Huntington's, amyotrophic lateral sclerosis, and other neurodegenerative diseases. ${ }^{[5]}$ Intuitively, the formation of RNA condensate should involve base-paired structure between the repeat-expansion sequences. ${ }^{[5 a]}$ Yet, little structural information is available for the RNA assembly in the condensed phase. ${ }^{[6]}$

Various spectroscopic methods have been utilized to characterize the structures of the macromolecules partitioned in the condensed phase. They include fluorescence correlation spectroscopy (FCS), ${ }^{[7]}$ single-molecule Förster resonance energy transfer (FRET) ${ }^{[8]}$ nuclear magnetic resonance (NMR), ${ }^{[9]}$ and Raman scattering spectroscopy ${ }^{[9 b, 10]}$. The use of fluorescence methods first requires covalent attachments of fluorophores, which may perturb the conformation of the subject molecule. In addition, the photophysical properties of the fluorophore may differ between dilute and condensed phases, ${ }^{[11]}$ complicating the estimation of condensed-phase properties. NMR spectroscopy in principle can provide a detailed structural picture of the macromolecules in the condensed phase. ${ }^{[9 a]}$ Yet successful acquisition of NMR data requires the coacervated macromolecules remain fluid and flexible in the droplets, which is often not the case.

Spontaneous Raman scattering spectroscopy arises from intrinsic molecular vibrations. As a result, the spectral features of Raman are not affected by the aggregation state of the macromolecule. ${ }^{[12]}$ Moreover, Raman characterization is labelfree and therefore is readily applicable for the coacervated macromolecules. Indeed, the method has been used to evaluate the concentration of ataxin- 3 protein $^{[10]}$, and to demonstrate the lack of any structural change of FUS protein in the condensed phase. ${ }^{[\mathrm{bb}]}$ However, spontaneous Raman spectroscopy cannot provide temporal information about macromolecular structural changes nor has sufficient spatial resolution for spectral imaging of the macromolecules in a droplet.

On the other hand, hyperspectral stimulated Raman microscope $(\mathrm{SRM})^{[13]}$ allows us to explore structural and molecular basis for the formation of RNA condensate (See methods and apparatus of SRM in Supplementary information, Figure S1). As a label-free and molecular imaging methods, SRM have been employed in a wide range of applications in biomedical imaging field. ${ }^{[14]}$ By fingerprinting the molecular vibrations, SRM is capable of identifying and mapping specific covalent bonds with sub- $\mu$ m resolution, ${ }^{[15]}$ thus well-suited for non-invasive and selective quantification of RNA structure in the droplets.

Previously, LLPS has been observed for RNA molecules with $>31 \times$ CAG repeats. ${ }^{[5 a]}$ We found that an RNA molecule with $20 \times C A G$ repeats can already phase separates, which occurs in the presence of a large excess of $\mathrm{Mg}^{2+}$ and is consistent with a recent report. ${ }^{[16]}$ Phase separation can be observed for the RNA molecule at as low as $9 \mu \mathrm{M}$ in concentration, while an increased RNA concentration promotes LLPS in both dimension and the number of the RNA droplets (Figure 1a).

To assess the fluidity of the RNA condensed phase, we conjugated a Cy5-dye at the 3 '-end of the $20 \times$ CAG-repeat RNA, and doped the labeled RNA to the unlabeled RNA. The RNA droplets did not fuse after an extended incubation time (Figure 1b), while the Cy5 fluorescence shows little to small recovery after photobleaching (FRAP) at various locations of the selected droplets (Figure 1c). As such, though the RNA molecule used 
bioRxiv preprint doi: https://doi.org/10.1101/2021.11.08.467691; this version posted November 8,2021 . The copyright holder for this preprint (which was not certified by peer review) is the author/funder, who has granted bioRxiv a license to display the preprint in perpetuity. It is made available under aCC-BY-NC-ND 4.0 International license.

here has fewer CAG repeats than previously reported, ${ }^{[5 a]}$ it also assembles to form largely immobilized droplets.

a RNA Concentration $(\mu \mathrm{M})$

9
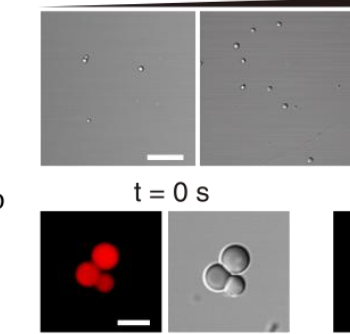

RNA: $35 \mu \mathrm{M} \quad \mathrm{MgCl}_{2}: 135 \mathrm{mM}$
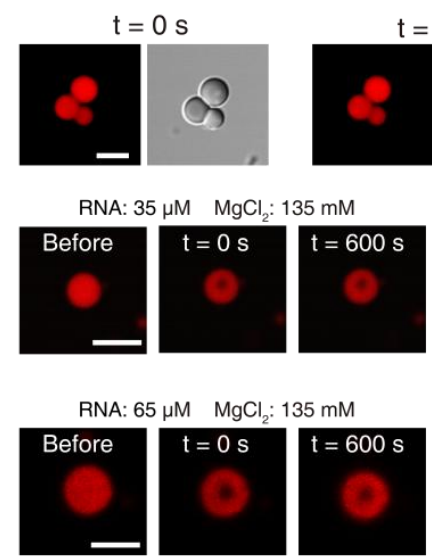

d

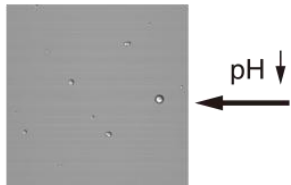

$\mathrm{pH}=4.0$
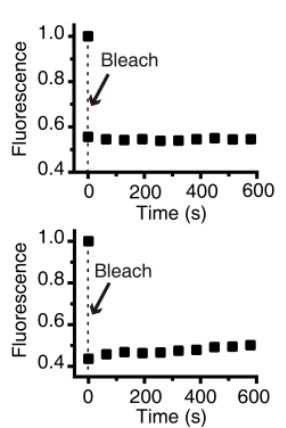

$=60 \mathrm{~s}$

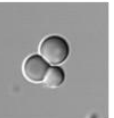

65 86
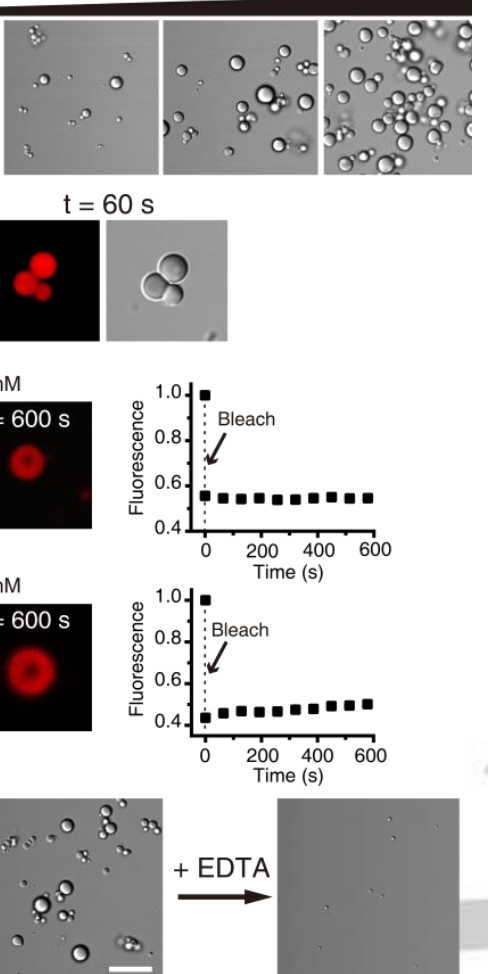

$\mathrm{pH}=7.0$
Figure 1. The 20×CAG repeat RNA oligonucleotide phase separates and forms gel-like condensate. a DIC images for the RNA droplets formed an increasing RNA concentration. The buffer contains $10 \mathrm{mM}$ Tris $\cdot \mathrm{HCl}$ at $\mathrm{pH} 7$ and $135 \mathrm{mM} \mathrm{MgCl}_{2}$. b The RNA droplets failed to fuse during the time of observation. c Fluorescence recovery after photobleaching (FRAP) measurement of the RNA droplets. Photo-bleaching of a droplet in the center, shows a lack of fluorescence recovery. Upper panel: FRAP measurement of the droplet formed by $35 \mu \mathrm{M} 20 \times \mathrm{CAG}$ and $135 \mathrm{mM} \mathrm{MgCl}_{2}$; Lower panel: FRAP measurement of the droplet formed by $65 \mu \mathrm{M} 20 \times \mathrm{CAG}$ and $135 \mathrm{mM} \mathrm{MgCl}_{2}$ d Lowering the $\mathrm{pH}$ or adding EDTA dissipates the droplets. Scale bars are 10 $\mu \mathrm{m}$ in $\mathrm{a}$ and $\mathrm{d}, 5 \mu \mathrm{m}$ in $\mathrm{b}$ and $\mathrm{c}$.

Though gel-like, the RNA droplets can be reversed and dissipated at an acidic $\mathrm{pH}$ (Figure 1d). On the other hand, increasing the concentration of $\mathrm{Mg}^{2+}$ can lead to the formation of larger RNA droplets (Figure 1c lower panel, and Figure S2). Conversely, the presence of a metal chelator, i.e., ethylenediaminetetraacetate (EDTA), nearly abolished the phase separation of the RNA molecules (Figure 1d). As such, the high-concentration of $\mathrm{Mg}^{2+}$ shields unfavorable electrostatic interactions between the RNA backbone, and consequently promotes intermolecular interactions.

When adding EDTA, we noticed that some of the droplets did not completely disappear, but instead morphed to a vesicle-like structure. Intrigued, we prepared the solutions with $86 \mu \mathrm{M}$ RNA and with different concentrations of $\mathrm{Mg}^{2+}$. In the presence of 135 $\mathrm{mM} \mathrm{Mg}^{2+}$, large droplets can be observed using differential interference contrast (DIC) microscopy (Figure 2a). In comparison, with lower concentrations of $\mathrm{Mg}^{2+}(60 \mathrm{mM}$ and 35 $\mathrm{mM}$ ) added to the same RNA solution, smaller RNA droplets are observed. Interestingly, in the presence of $35 \mathrm{mM} \mathrm{Mg}^{2+}$, the $20 \times$ CAG RNA molecules phase-separate to form hollow vesiclelike structure (Figure 2a, right panel).
For those apparently hollow RNA droplets, fluorescence confocal microscopy imaging indicates that the RNA concentration is indeed lower at the center than at the rim (Figure 2b). To rule out aggregation-caused fluorescence quenching, we resorted to Raman spectroscopy. The Raman band at $1100 \mathrm{~cm}^{-1}$ arises from symmetric stretching of RNA phosphate backbone, and its intensity is proportional to the overall concentration of nucleobases and is insensitive to RNA structural changes. ${ }^{[12 a, 17]}$ The $1100 \mathrm{~cm}^{-1}$ Raman band intensity indicates that the RNA molecule is about twice as concentrated at the rim of the vesicles (Figure 2c), consistent with the fluorescence microscopy observation. The hollow RNA droplets remain gel-like, as multiple droplets can form a complex and multi-chamber structure (Supporting Information, Figure S3).

a $\mathrm{Mg}^{2+}$ Concentration $(\mathrm{mM})$ 135
60

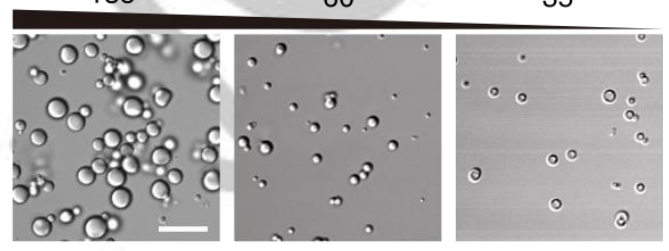

Cy5

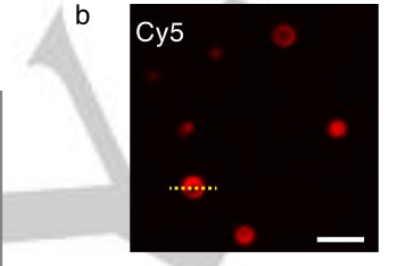

C SRS
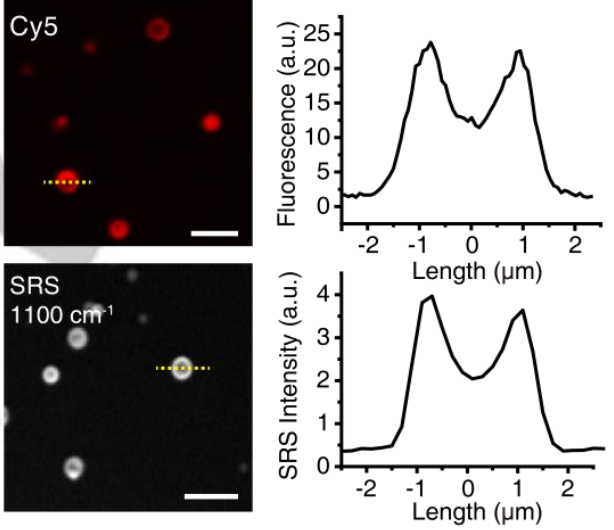

Figure 2. Formation of vesicle-like RNA droplets. a DIC images of droplets formed by $86 \mu \mathrm{M} 20 \times \mathrm{CAG}$ RNA at three $\mathrm{Mg}^{2+}$ concentrations. b Fluorescence intensity analysis of a hollow RNA droplet structure formed by $86 \mu \mathrm{M} 20 \times C A G$ and $35 \mathrm{mM} \mathrm{MgCl}_{2}$, with Cy5-conjugated RNA was doped with unlabeled RNA. c Analysis of Raman spectral intensity at $1100 \mathrm{~cm}^{-1}$ of a selected droplet. The intensities were assessed along the dashed line, with a pixel resolution of 0.2 $\mu \mathrm{m}$. Scale bars are $10 \mu \mathrm{m}$ in a, $5 \mu \mathrm{m}$ in b and c.

While keeping the $\mathrm{Mg}^{2+}$ concentration constant at $135 \mathrm{mM}$, we prepared the solutions of $20 \times \mathrm{CAG}$ RNA at $35 \mu \mathrm{M}$ and $65 \mu \mathrm{M}$, respectively. The RNA molecules can readily phase separate at both concentrations (Figure $\mathbf{3 a}$, left and middle panels). Furthermore, at a higher RNA concentration $(86 \mu \mathrm{M})$ but a lower $\mathrm{Mg}^{2+}$ concentration (35 $\left.\mathrm{mM}\right)$, the RNA droplets are smaller and hollow (Figure 3a, right panel). As such, the morphology of the RNA condensate depends on the relative RNA/ $\mathrm{Mg}^{2+}$ ratio. We name these three morphologies as type I, II, and III droplets. Assessed with the Raman intensity at $1100 \mathrm{~cm}^{-1}$, type-II RNA droplets are larger than type-I droplets, and have a higher enrichment of the RNA molecules (Figure 3b,c). The three types of RNA droplets have the diameters of $3.0 \pm 0.7 \mu \mathrm{m}$, $4.4 \pm 0.7 \mu \mathrm{m}$, and $2.4 \pm 0.7 \mu \mathrm{m}$, respectively (Figure $3 \mathrm{~d}$ ). Interestingly, though prepared from the highest RNA concentration, the type-III vesicle-like droplets are the smallest and have the lowest enrichment ratio (Figure 3c), which further attests the importance of $\mathrm{Mg}^{2+}$ in RNA coacervation. 
bioRxiv preprint doi: https://doi.org/10.1101/2021.11.08.467691; this version posted November 8,2021 . The copyright holder for this preprint (which was not certified by peer review) is the author/funder, who has granted bioRxiv a license to display the preprint in perpetuity. It is made available under aCC-BY-NC-ND 4.0 International license.
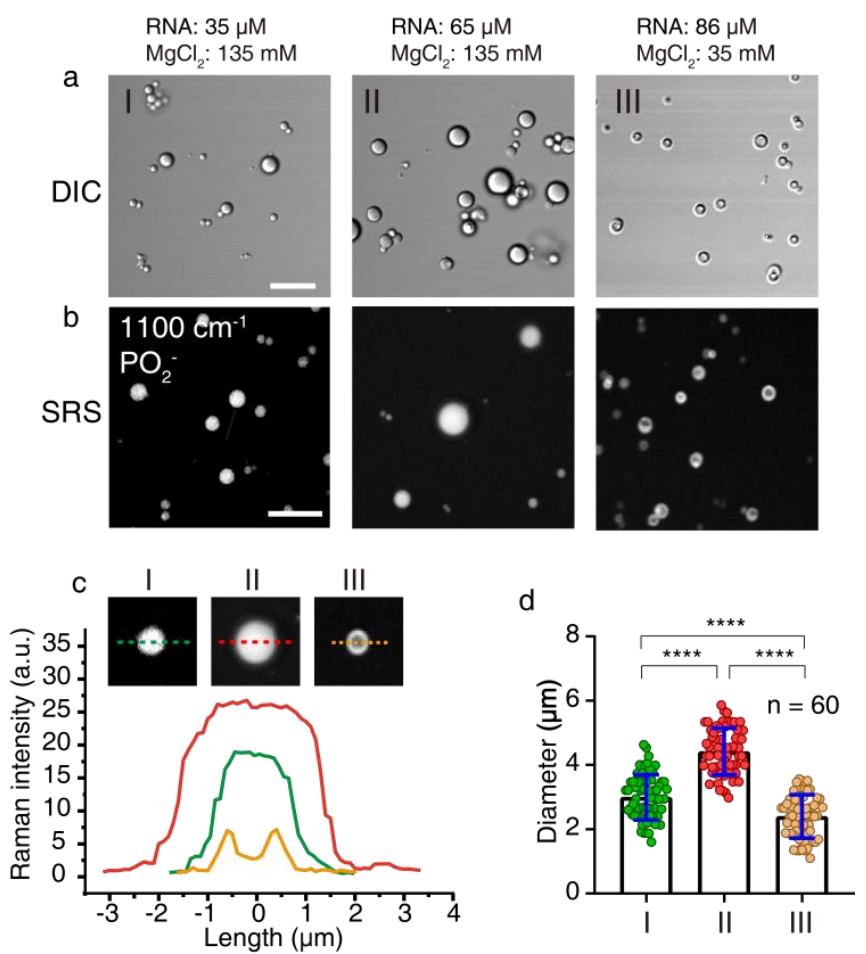

Figure 3. Morphology of the RNA droplets at different $\mathrm{RNA} / \mathrm{Mg}^{2+}$ ratios. a,b DIC and SRM images at $1100 \mathrm{~cm}^{-1}$ for the RNA droplets formed with 35 $\mu \mathrm{M}$ RNA and $135 \mathrm{mM} \mathrm{MgCl}_{2}$ (morphology I), $65 \mu \mathrm{M} \mathrm{RNA}$ and $135 \mathrm{mM} \mathrm{MgCl}$ (morphology II), and $86 \mu \mathrm{M}$ RNA and $35 \mathrm{mM} \mathrm{MgCl}_{2}$ (morphology III). c The Raman intensities at $1100 \mathrm{~cm}^{-1}$ along the dashed lines for type-I, II and III droplets. d Statistics of the diameters of the RNA droplets for the three morphologies in DIC images. $n=60$ and $p<0.0001$. Scale bars, $10 \mu \mathrm{m}$.

To understand the molecular basis that leads to the formation of RNA condensate, we collected spontaneous Raman spectra of the 20×CAG RNA in the dilute and condensed phases. With the RNA concentration in the two phases normalized by the intensity of the Raman peak at $1100 \mathrm{~cm}^{-1}$, we assessed the relative intensities for other Raman bands. It has been established that upon the formation of an RNA duplex or hairpin, hypochromicity is observed for Raman spectral bands between 600 and $800 \mathrm{~cm}^{-1}$. In particular, hypochromicity for $727 \mathrm{~cm}^{-1}$ and $785 \mathrm{~cm}^{-1}$ bands have been attributed to the decrease of ring breathing in the base-paired RNA for adenine and cytosine nucleobases, respectively. ${ }^{[12 a, 18]}$ On the other hand, hyperchromicity is observed for Raman spectral bands between 1200 and $1600 \mathrm{~cm}^{-1}$. In particular, the $1250 \mathrm{~cm}^{-1}, 1481 \mathrm{~cm}^{-1}$, and $1577 \mathrm{~cm}^{-1}$ bands $^{[17 \mathrm{c}, 19]}$ increase in intensities upon the formation of canonical RNA secondary structures, which is resulted from the increased ring stretching and collective vibration, ${ }^{[12 a, 17 c, 20]}$ as well as increased base stacking and clustering. ${ }^{[12 a, 21]}$

We show that, upon the coacervation of the repeat-expansion RNA molecules, the Raman intensities for 727 and $785 \mathrm{~cm}^{-1}$ bands are higher in the droplets than in the dilute phase (Figure 4). The $20 \times C A G$ RNA is predicted to form a stable hairpin structure, and may also hybridize to form a duplex (Figure S4) depending on the annealing condition. The increased Raman intensities at $727 \mathrm{~cm}^{-1}$ and $785 \mathrm{~cm}^{-1}$ indicate that the RNA in the condensed phase contains less base-paired structure. Specifically, the Raman intensities at $727 \mathrm{~cm}^{-1}$ and $785 \mathrm{~cm}^{-1}$ are 3.5-fold and 2.6-fold higher in the droplets, respectively, suggesting non-canonical base pairs involving adenines ${ }^{[22]}$ are more easily disrupted upon RNA coacervation. The increase of more single-stranded RNA regions may also be due to steric hindrance, which precludes proper base paring and the formation of RNA duplex or hairpin in a crowded environment.

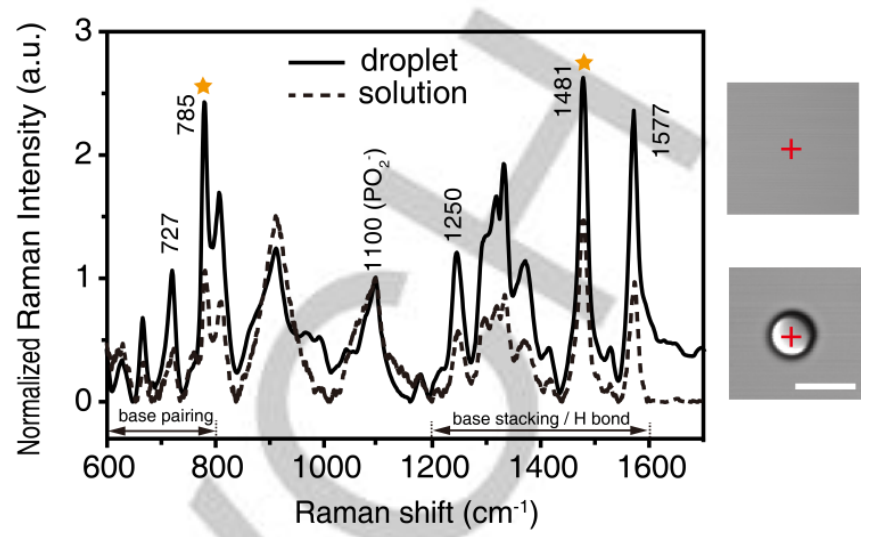

Figure 4. Spontaneous Raman Spectrum of a representative RNA droplet. The droplets were prepared with $65 \mu \mathrm{M} 20 \times \mathrm{CAG}$ repeat RNA, $135 \mathrm{mM} \mathrm{MgCl} 2$ in the $10 \mathrm{mM}$ Tris $\bullet \mathrm{HCl} \mathrm{pH} 7$ buffer. As a control, the Raman spectrum was collected for the RNA solution at $1.7 \mathrm{mM}$ with no annealing treatment. Scale bar, $5 \mu \mathrm{m}$. The starred peaks are further subjected to stimulated Raman spectroscopy analysis.

On the other hand, the Raman intensities at $1250 \mathrm{~cm}^{-1}, 1481$ $\mathrm{cm}^{-1}$, and $1577 \mathrm{~cm}^{-1}$ are higher in the condensed phase than in the dilute phase (Figure 4). As such, the nucleobases likely stack and cluster together in the droplets as opposed to the canonical hydrogen-bonding and base-pairing associated with the A-form duplex or hairpin structure. The stacking/clustering should involve stacking between RNA single-stranded regions ${ }^{[23]}$ or stacking between multiple nucleobases. ${ }^{[24]}$

To map the location-specific RNA structure in the condensed phase, we employed $\mathrm{SRM}^{[13 \mathrm{a}]}$ and collected a hyperspectral stack of Raman images at wavelengths from 650 to $1600 \mathrm{~cm}^{-1}$ for the three types of RNA droplets. After normalizing by the Raman intensity at $1100 \mathrm{~cm}^{-1}$, the intensity differences at other wavelengths become obvious (Figure S5). The Raman intensities at $785 \mathrm{~cm}^{-1}$ and $1481 \mathrm{~cm}^{-1}$ are just slightly higher at the center than at the rim of the type-I droplet (Figure $5 \mathbf{a}, \mathbf{g}$ ). In contrast, the Raman intensities at $785 \mathrm{~cm}^{-1}$ and $1481 \mathrm{~cm}^{-1}$ are lower at the center than at the rim of the type-II and type-III droplets. This means, at the center of these two types of RNA droplets, the RNA structure is more based-paired but less clustered (Figure $\mathbf{5 b}, \mathbf{c}, \mathbf{h}, \mathbf{i}$ ), akin the RNAs in a dilute phase.

Further, we measured the radial distributions of Raman intensities at various wavelengths (Figure S6). For the type-I droplets, the $758 \mathrm{~cm}^{-1}$ and $1481 \mathrm{~cm}^{-1}$ Raman intensities at the rim are nearly comparable to those at the center, meaning a quite homogenous architecture (Figure $5 \mathbf{d}$, j). On the other hand, both type-II and type-III droplets have well-defined rims, which are characterized by sharp transitions in Raman intensities (Figure $5 \mathbf{e}, \mathbf{f}, \mathbf{k}, \mathbf{l})$. As such, the type-ll droplets also form a vesicle-like structure, even though they do not appear so under the light microscopy. Thus, the hollowing of RNA droplets correlates with the increase of $\mathrm{RNA} / \mathrm{Mg}^{2+}$ ratio, and the RNA molecules tend to cluster and stack at the rims of both type-II and type-III droplets (Figure 6).

In summary, we have used SRM to uncover the structural features of a condensed phase, homotypically formed by a $20 \times C A G$ repeat RNA molecule. The addition of a large excess of divalent cation neutralizes electrostatic repulsions between RNA 
bioRxiv preprint doi: https://doi.org/10.1101/2021.11.08.467691; this version posted November 8, 2021. The copyright holder for this preprint (which was not certified by peer review) is the author/funder, who has granted bioRxiv a license to display the preprint in perpetuity. It is made available under aCC-BY-NC-ND 4.0 International license.

molecules, as previously shown. ${ }^{[16]}$ Significantly, Raman spectroscopic analysis indicates that the stacking and clustering of the nucleobases, instead of hydrogen-bonding and canonical base pairing, contribute to the formation of the RNA droplets (Figure 4). Indeed, partial protonation of the $\mathrm{N}^{3}$ atom of cytosine and $\mathrm{N}^{1}$ atom of adenine nucleobases at an acidic $\mathrm{pH}^{[25]}$ would disrupt nucleobase clustering and dissipates RNA droplets, as we show in Figure 1d.

\section{$785 \mathrm{~cm}^{-1} / 1100 \mathrm{~cm}^{-1}$}
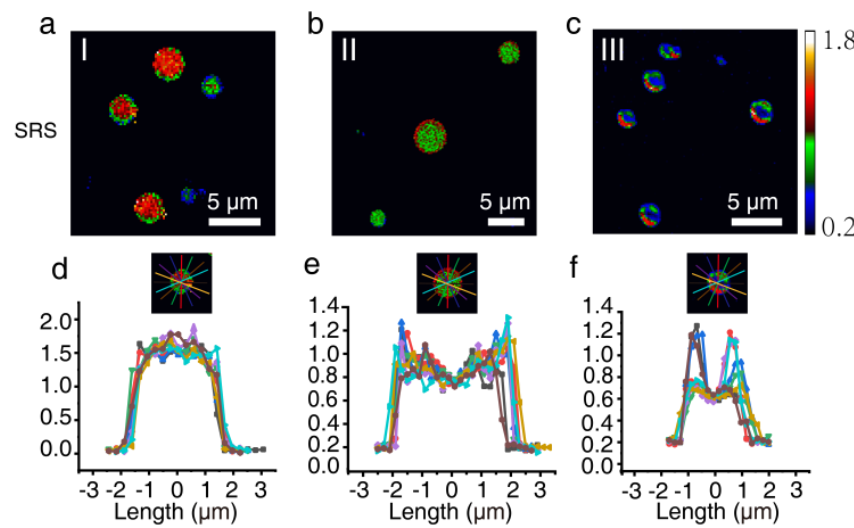

$1481 \mathrm{~cm}^{-1} / 1100 \mathrm{~cm}^{-1}$
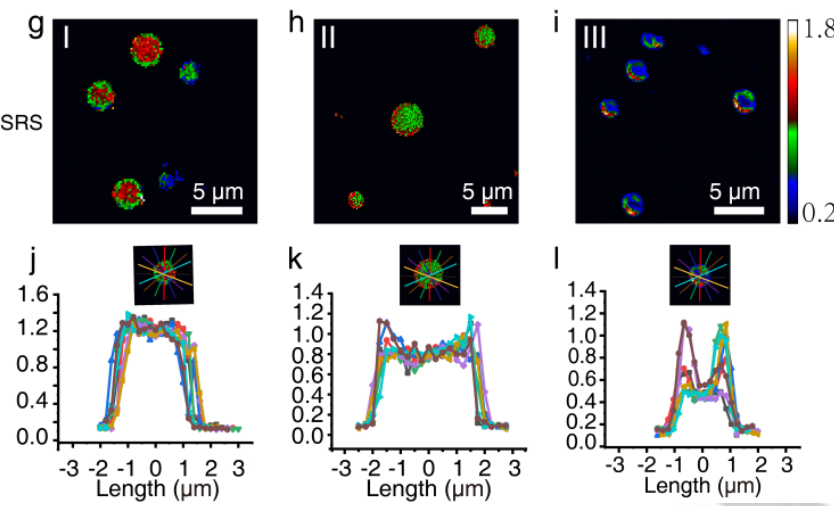

Figure 5. Hyperspectral stimulated Raman scattering microscopy analysis of the three types of RNA droplets. a-c, g-i SRM images at 785 $\mathrm{cm}^{-1}$ and $1480 \mathrm{~cm}^{-1}$, respectively. d-f, j-I Quantitative assessment of the inhomogeneous distribution of the RNA structures within the droplets. Each line indicates an arbitrary line across a selected droplet at $785 \mathrm{~cm}^{-1}$ and 1480 $\mathrm{cm}^{-1}$, respectively. The intensities are normalized to Raman intensity at 1100 $\mathrm{cm}^{-1}$. Scale bars, $5 \mu \mathrm{m}$.

Depending on the RNA/Mg ${ }^{2+}$ ratio, we also show that the RNA droplets adopt different architectures and morphologies. When the $\mathrm{Mg}^{2+}$ concentration decreases, the repulsion between the phosphate backbone increases. With less counterion present, the RNA droplets become gradually hollowed, while nucleobase stacking and clustering, a form of hydrophobic interactions, become more dominant for the formation of RNA droplets. Ultimately, the RNA molecules form a vesicle-like structure, with the center containing much fewer molecules and a less nucleobase-clustered structure (Figure 6). In comparison to base pairing, nucleobase clustering can be more restrictive, affording a large network of intermolecular interactions. Indeed, the FRAP experiment reveals a partial recovery of the fluorescence for the type-II droplets (Figure 1c, lower panel, and Figure S7), corroborating the SRM results.

Our finding thus has broader implications in the active research field of phase separation. When co-phase separated with proteins, RNA molecules are often found absorbed at the surface of those droplets. ${ }^{[4 \mathrm{~d}, 26]}$ Moreover, the RNA component has been shown to limit the size of RNA-protein condensate. ${ }^{[27]}$ Since the interwoven nucleobase-clustered RNA assembly is likely mechanically rigid, a protective RNA shell would define the physical boundaries of membrane-less organelles. In this regard, the repeat-expansion RNA molecules act as a Pickering agent, ${ }^{[28]}$ as recently ascribed for MEG-3 protein absorbed at the surface of $\mathrm{P}$ granules. ${ }^{[29]}$

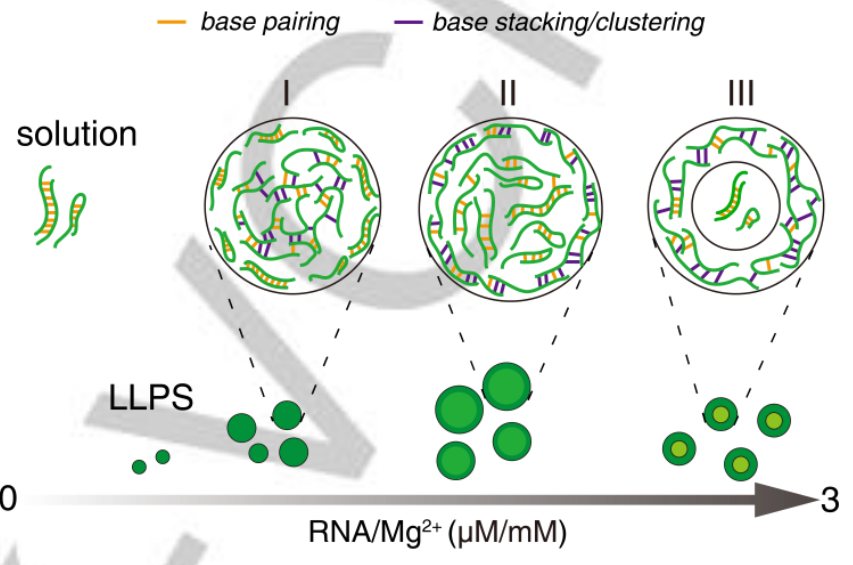

Figure 6. Schematic for the different structures of RNA droplets formed by $20 \times$ CAG at different $\mathrm{RNA} / \mathbf{M g}^{2+}$ ratios. When the RNA concentration increases or $\mathrm{Mg}^{2+}$ concentration decreases, the RNA molecules are more likely to phase-separate into type-II and type-III droplets, with the outer rim containing a large proportion of stacked/clustered nucleobases.

\section{Acknowledgements}

The work was supported by the National Key R\&D Program of China (2018YFA0507700 to C.T.) and the National Natural Science Foundation of China (31971155 to Z.G.). P.W. acknowledges the supports from the National Natural Science Foundation of China 62075076 and Innovation Fund of the Wuhan National Laboratory for Optoelectronics.

Keywords: phase separation - Raman spectroscopy • RNA • base stacking • repeat expansion

[1] (a) P. Anderson, N. Kedersha, Nat. Rev. Mol. Cell Biol. 2009, 10, 430 436; (b) J. Berry, S. C. Weber, N. Vaidya, M. Haataja, C. P. Brangwynne, Proc Natl Acad Sci U S A 2015, 112, 5237-5245; (c) B. Tsang, J. Arsenault, R. M. Vernon, H. Lin, N. Sonenberg, L. Y. Wang, A. Bah, J. D. Forman-Kay, Proc Natl Acad Sci U S A 2019, 116, 42184227; (d) T. J. Nott, E. Petsalaki, P. Farber, D. Jervis, E. Fussner, A Plochowietz, T. D. Craggs, D. P. Bazett-Jones, T. Pawson, J. D. Forman-Kay, A. J. Baldwin, Mol. Cell 2015, 57, 936-947; (e) H. Zhang, X. Ji, P. L. Li, C. Liu, J. Z. Lou, Z. Wang, W. Y. Wen, Y. Xiao, M. J. Zhang, X. L. Zhu, Sci China Life Sci 2020, 63, 953-985; (f) M. M. Fay, P. J. Anderson, J. Mol. Biol. 2018, 430, 4685-4701; (g) M. Polymenidou, Science 2018, 360, 859-860.

[2] (a) A. Molliex, J. Temirov, J. Lee, M. Coughlin, A. P. Kanagaraj, H. J. Kim T. Mittag, J. P. Taylor, Cell 2015, 163, 123-133; (b) Y. Shin, C. P. Brangwynne, Science 2017, 357.

[3] M. Fuxreiter, M. Vendruscolo, Nat. Cell Biol. 2021, 23, 587-594.

[4] (a) P. R. Banerjee, A. N. Milin, M. M. Moosa, P. L. Onuchic, A. A. Deniz Angew. Chem. Int. Ed. 2017, 56, 11354-11359; (b) S. Maharana, J. Wang, D. K. Papadopoulos, D. Richter, A. Pozniakovsky, I. Poser, M. Bickle, S. Rizk, J. Guillen-Boixet, T. M. Franzmann, M. Jahnel, L. Marrone, Y. T. Chang, J. Sterneckert, P. Tomancak, A. A. Hyman, S. 
bioRxiv preprint doi: https://doi.org/10.1101/2021.11.08.467691; this version posted November 8, 2021. The copyright holder for this preprint (which was not certified by peer review) is the author/funder, who has granted bioRxiv a license to display the preprint in perpetuity. It is made available under aCC-BY-NC-ND 4.0 International license.

Alberti, Science 2018, 360, 918-921; (c) S. Boeynaems, A. S. Holehouse, V. Weinhardt, D. Kovacs, J. Van Lindt, C. Larabell, L. Van Den Bosch, R. Das, P. S. Tompa, R. V. Pappu, A. D. Gitler, Proc Natl Acad Sci U S A 2019, 116, 7889-7898; (d) I. Alshareedah, M. M. Moosa, M. Raju, D. A. Potoyan, P. R. Banerjee, Proc Natl Acad Sci U S A 2020, $117,15650-15658$

[5] (a) A. Jain, R. D. Vale, Nature 2017, 546, 243-247; (b) M. M. Fay, P. J. Anderson, P. Ivanov, Cell Rep. 2017, 21, 3573-3584; (c) Y. Teng, H. Tateishi-Karimata, N. Sugimoto, Biochemistry 2020, 59, 1972-1980.

[6] P. C. Bevilacqua, A. M. Williams, H. L. Chou, S. Assmann, RNA 2021, pp 1-28.

[7] S. Peng, W. Li, Y. Yao, W. Xing, P. Li, C. Chen, Proc Natl Acad Sci USA 2020, 117, 27124-27131.

[8] (a) S. Elbaum-Garfinkle, Y. Kim, K. Szczepaniak, C. C. H. Chen, C. R. Eckmann, S. Myong, C. P. Brangwynne, Proc Natl Acad Sci USA 2015 112, 7189-7194; (b) I. Nasir, P. L. Onuchic, S. R. Labra, A. A. Deniz, BBA Proteins and Proteomics 2019, 1867, 980-987.

[9] (a) J. P. Brady, P. J. Farber, A. Sekhar, Y. H. Lin, R. Huang, A. Bah, T. J. Nott, H. S. Chan, A. J. Baldwin, J. D. Forman-Kay, L. E. Kay, Proc Natl Acad Sci U S A 2017, 114, 8194-8203; (b) A. C. Murthy, G. L. Dignon, Y. Kan, G. H. Zerze, S. H. Parekh, J. Mittal, N. L. Fawzi, Nat. Struct. Mol. Biol. 2019, 26, 637-648.

[10] K. Murakami, S. Kajimoto, D. Shibata, K. Kuroi, F. Fujii, T. Nakabayashi, Chem. Sci. 2021, 12, 7411-7418.

[11] Y. Li, S. Liu, H. Ni, H. Zhang, H. Zhang, C. Chuah, C. Ma, K. S. Wong, J. W. Y. Lam, R. T. K. Kwok, J. Qian, X. Lu, B. Z. Tang, Angew. Chem. Int. Ed. 2020, 59, 12822-12826.

[12] (a) A. J. Hobro, D. M. Standley, S. Ahmad, N. I. Smith, Phys. Chem. Chem. Phys. 2013, 15, 13199-13208; (b) A. L. Wilson, C. Outeiral, S. E. Dowd, A. J. Doig, P. L. A. Popelier, J. P. Waltho, A. Almond, Chemi. Commun. 2020, 3

[13] (a) M. C. Wang, W. Min, C. W. Freudiger, G. Ruvkun, X. S. Xie, Nature Methods 2011, 8, 135-152; (b) Y. Bi, C. Yang, Y. Chen, S. Yan, G. Yang, Y. Wu, G. Zhang, P. Wang, Light Sci. Appl. 2018, 7.

[14] (a) M. Ji, M. Arbel, L. Zhang, C. W. Freudiger, S. S. Hou, D. Lin, X. Yang, B. J. Bacskai, X. S. Xie, Sci. Adv. 2018, 4; (b) D. Zhang, P. Wang M. N. Slipchenko, J. X. Cheng, Acc. Chem. Res. 2014, 47, 2282-2290.

[15] L. Wei, F. Hu, Z. Chen, Y. Shen, L. Zhang, W. Min, Acc. Chem. Res. 2016, 49, 1494-1502.

[16] P. L. Onuchic, A. N. Minn, I. Alshareedah, A. A. Deniz, P. R. Banerjee, Sci. Rep. 2019, 9.

[17] (a) B. Gong, J. H. Chen, R. Yajima, Y. Y. Chen, E. Chase, D. M. Chadalavada, B. L. Golden, P. R. Carey, P. C. Bevilacqua, Methods 2009, 49, 101-111; (b) P. Carmona, M. Molina, A. Rodriguez-Casado J Raman Spectrosc 2009, 40, 893-897; (c) J. Morla-Folch, H. N. Xie, R. A. Alvarez-Puebla, L. Guerrini, Acs Nano 2016, 10, 2834-2842.

[18] M. C. Chen, G. J. Thomas, Biopolymers 1974, 13, 615-626.

[19] Y. Li, T. Gao, G. Xu, X. Xiang, B. Zhao, X. X. Han, X. Guo, Anal. Chem. 2019, 91, 7980-7984.

[20] (a) G. J. Thomas, M. C. Chen, K. A. Hartman, Biochimica et Biophysica Acta 1973, 324, 37-49; (b) A. J. Hobro, M Rouhi, E. W. Blanch, G. L. Conn, Nucleic Acids Res. 2007, 35, 11691177.

[21] B. Hernandez, V. Baumruk, N. Leulliot, C. Gouyette, T. Huynh-Dinh, M. Ghomi, J. Mol. Struct. 2003, 651, 67-74.

[22] N. B. Leontis, J. Stombaugh, E. Westhof, Nucleic Acids Res. 2002, 30 , 3497-3531.

[23] B. Van Treeck, R. Parker, Cell 2018, 174, 791-802.

[24] A. M. Williams, R. R. Poudyal, P. C. Bevilacqua, Biochemistry 2021, 60, 2715-2726.

[25] (a) R. Krishnamurthy, Acc. Chem. Res. 2012,45, 2035-2044; (b) P. Thaplyal, P. C. Bevilacqua, Chapter Nine - Experimental Approaches for Measuring pKa's in RNA and DNA. In Methods in Enzymology, Burke-Aguero, D. H., Ed. Academic Press, 2014, pp 189-219.

[26] A. Cochard, G. J. Navarro, S. Kashida, M. Kress, Z. Gueroui, 2021.

[27] M. Garcia-Jove Navarro, S. Kashida, R. Chouaib, S. Souquere, G. Pierron, D. Weil, Z. Gueroui, Nat. Commun. 2019, 10, 3230.

[28] A. B. Pawar, M. Caggioni, R. W. Hartel, P. T. Spicer, Faraday Discuss. 2012, 158, 341-350.
[29] A. W. Folkmann, A. Putnam, C. F. Lee, G. Seydoux, Science 2021, 373, 1218-1224. 
bioRxiv preprint doi: https:/doi.org/10.1101/2021.11.08.467691; this version posted November 8, 2021. The copyright holder for this preprint (which was not certified by peer review) is the author/funder, who has granted bioRxiv a license to display the preprint in perpetuity. It is made available under aCC-BY-NC-ND 4.0 International license.

\section{Entry for the Table of Contents}

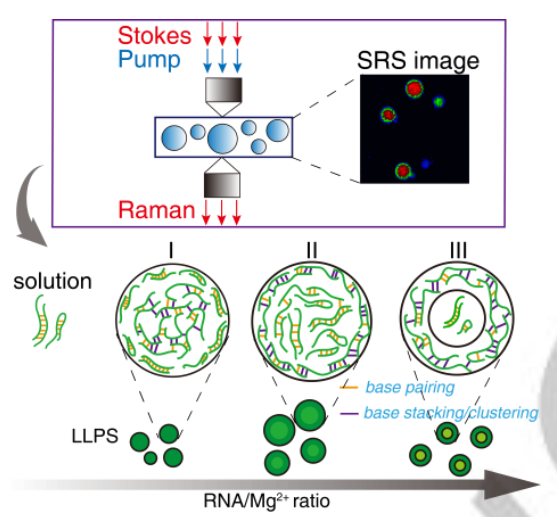

Phase separation of repeat expansion RNA molecules leads to the formation of gel-like droplets. Ma et. al showed that depending on the $\mathrm{RNA} / \mathrm{Mg}^{2+}$ ratio, a 20×CAG repeat RNA forms small, large, and hollow droplets. Using hyperspectral stimulated Raman spectroscopy, they demonstrated that nucleobase clustering is a driving force for RNA coacervation, and is predominant at the rim of large and hollow droplets.

Institute Twitter username: @PKU_1898

Researcher Twitter username: @Chun_Tang 